\title{
PENGARUH LIMBAH SAMPAH TYPE HDPE (HIGH DENSITY POLYTHYLENE) PADA LAPISAN ASPAL AC WC
}

\author{
Okky Hendra $\mathrm{H}^{1}$, Nurdiana yusuf ${ }^{2}$, Isradias Mirajhusnita ${ }^{3}$, Teguh Haris ${ }^{4}$, Weimintoro ${ }^{5}$ \\ Teknik Sipil, Fakultas Teknik, Universitas Pancasakti Tegal \\ ${ }^{1}$ E-mail: okijavva@gmail.com
}

\begin{abstract}
ABSTRAK: Meningkatnya mobilisasi penduduk memunculkan kendaraan-kendaraan baru baik kendaraan ringan sampai dengan kendaraan berat yang meIintas dijalan raya, sehingga dibutuhkan juga sarana penunjang transportas yang cukup memadai untuk menampung volume kendaraan yang akan meIintas diatasnya. Karena itu peneIiti akan mencoba untuk meIakukan peneIitian dengan cara memanfaatkan limbah plastik jenis HDPE ( High Density Polyethylene) untuk campuran aspal tersebut sesuai dengan acuan pada SNI Bina Marga 2010 dengan menggunakan metode Marshall Test. Penambahan plastik yang digunakan ada 3 variasi yaitu dengan campuran plastik 5\%, 7,5\% dan 10\%. Dari pengujian Stabilitas Marshall yang dilakukan dengan penambahan plastik 5\% nilai nya sebesar $2843,5 \mathrm{~kg}$, dan 7,5\% dengan nilai $2695,8 \mathrm{~kg}$ dan $10 \%$ dengan nilai $2455,0 \mathrm{~kg}$, pengujian Flow / kelelehan dengan penambahan plastik 5\% sebesar 4,91\%, dan 7,5\% sebesar 4,26\% dan 10\% sebesar 1,63\%. Pengujian Marshall Quotient untuk penambahan plastik 5\% sebesar 655,39 kg/mm, dan 7,5\% sebesar 704,38 kg/mm, dan untuk 10\% sebesar 1714,02 kg/mm.
\end{abstract}

Kata Kunci : Marshall Test, plastic waste, asphalt (AC-WC)

\section{PENDAHULUAN}

Jalan memungkinkan seluruh masyarakat mendapatkan akses pelayanan pendidikan, kesehatan, perdagangan dan pekerjaan lainnya. Untuk itu diperlukan perencanaan struktur perkerasan yang kuat, tahan lama dan mempunyai daya tahan tinggi terhadap deformasi plastis yang terjadi. Dewasa ini perkembangan dan pertumbuhan penduduk sangat pesat, seiring dengan hal tersebut mengakibatkan meningkatnya peningkatan mobilisasi penduduk, sehingga muncul kendaraankendaraan baru baik kendaraan ringan sampai dengan kendaraan berat yang melintas dijalan raya. Dibutuhkan juga sarana penunjang transportasi yang cukup memadai untuk menampung volume kendaraan yang akan melintas diatasnya.

Seiring dengan perkembangan zaman, penawaran dan permintaan dari penggunaan plastik pun meningkat pada sektor industri atau masyarakat. Namun dengan adanya peningkatan penggunaan dari plastik maka limbah yang berupa sampah plastik pun meningkat. Plastik merupakan polimer hidrokarbon yang sulit terurai. Sehingga banyak sampah plastik yang tertimbun dan tidak terolah dengan baik dan benar. Hal ini merupakan salah satu permasalahan bagi indonesia dan perlu penanganan yang baik. Umumnya dimasyarakat maupun di di TPA (Tempat Pembuangan Akhir), timbunan sampah plastik dibakar untuk mengurangi jumlah sampah plastik yang ada.

Plastik memiliki banyak manfaat tetapi juga memiliki sisi negatif khususnya limbah plastik, namun limbah plastik ini membuka peluang untuk dimanfaatkan dalam bidang konstruksi jalan raya. Campuran aspal memiliki beberapa kelemahan seperti mengalami deformasi (perubahan bentuk) permanen disebabkan oleh tekanan yang terlalu berat seperti muatan truk yang berlebihan, keretakan-keretakan yang ditimbulkan oleh panas, dan juga disebabkan oleh kelembaban, ini semua terjadi pada campuran aspal (Brown, 1990).

Sampah plastik yang digunakan pada penelitian kali ini adalah sampah plastik jenis HDPE ( High Density Polyethylene), yang merupakan bahan baku jenis plastik HDPE dimana umumnya hasil produksi berbentuk kantong plastik, plastik roll dan plastik lembaran. Masyarakat indonesia dalam kesehariannya mengenal kantong plastik HDPE dengan sebutan kantong HD, kantong kresek, kantong asoy, tas plastik HD, ataupun shopping bag. Mengacu pada urain di atas maka penulis ingin melakukan penelitian untuk mengetahui pengaruh yang dihasilkan terhadap limbah sampah type HDPE (High Density Polythylene) pada lapisan aspal AC WC sebagai bahan karakteristik campuran pembuatannya.

\section{METODELOGI PENELITIAN}

Metode Penelitian yang digunakan ini adalah dengan metode eksperimen, dimana dalam penelitian kali ini penulis akan menganalisa tentang pemanfaatan Limbah plastik jenis HDPE ( High Density Poly-Ethylene ) Sebagai Bahan Campuran Lapis Aspal AC-WC Dengan Metode Marshall test ( SNI BINA MARGA TAHUN 2010 ), dengan perbandingan variasi tambahan limbah plastik HDPE dengan campuran aspal 5\%, 7,5\% dan 10\%. Serta dengan pembuatan sampel sebanyak 5 sampel benda uji dengan kandungan plastik yang berbeda.

Adapun varibel dalam penelitian ini adalah :

1) Variabel Bebas

Bahan atau agregat yang sudah diuji sifat fisiknya untuk terjaminnya kesesuaian bahan yang akan digunakan dalam campuran beton aspal. Agregat dalam campuran beton aspal akan dibuat komposisi campuran.

Bahan atau agregat yang digunakan dalam komposisi campuran aspal beton melewati proses pengujian sifat dan pengujian fisiknya sesuai spesifikasi. Sebelum menjadi campuran aspal agregat yang akan digunakan dibuatkan komposisi.

2) Variabel Terikat

Didalam penelitian pemanfaatan Limbah plastik jenis HDPE ( High Density Poly-Ethylene ) Sebagai Bahan Campuran Lapis Aspal AC-WC Dengan Metode Marshall test.

Jenis aspal yang diteliti adalah jenis pertamina 60/70, lapisan Aspal jenis AC-WC merupakan lapisan yang terletak diposisi paling atas, lapisan aspal AC-WC adalah lapisan yang memiliki struktur paling halus dibandingkan dengan lapisan lainnya.

Selengkapnya metode penelitian ini terdapat Pada gambar 1 Diagaram Penelitian. 


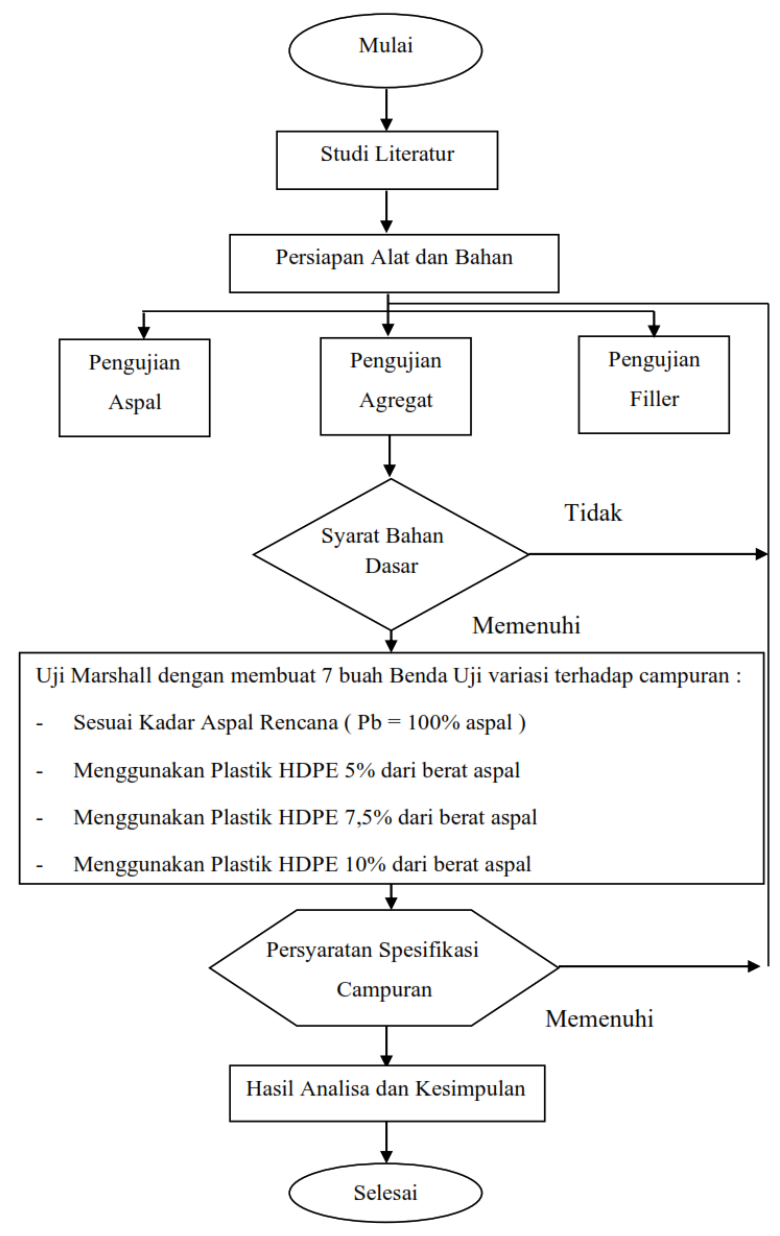

\section{HASIL DAN PEMBAHASAN}

Dari hasil pengujian Marshall dengan variasi kadar aspal $60 / 70$ pen dan pencampuran plastik dengan variasi plastik 5\%, 7,5\% dan $10 \%$. Dengan mencari nilai stabilitas, kelelehan (flow), , rongga terisi aspal (VFB), rongga dalam campuran (VIM), rongga dalam agregat (VMA), dan Marshall Quotien (MQ).

Dari hasil pengujian Marshall test dengan penambahan plastik jenis HDPE dapat disajikan pada Tabel 1. Dibawah ini

Gambar 1. Diagram Alir Penelitian

Table 1. Hasil pengujian Marshall Test dengan penambahan Plastik HDPE dengan Variasi 5\%, 7,5\% dan 10\%

\begin{tabular}{|c|c|c|c|c|c|c|c|c|}
\hline \multirow{2}{*}{$\begin{array}{l}\text { Hasil } \\
\text { Pemeriksaan }\end{array}$} & \multicolumn{7}{|c|}{ Penambahan Plastik 5\% } & \multirow[t]{2}{*}{ Spesifikasi } \\
\hline & 1 & 2 & 3 & 4 & 5 & 6 & 7 & \\
\hline \multirow{2}{*}{$\begin{array}{l}\text { Kepadatan } \\
\text { (gr/ml) }\end{array}$} & 2,121 & 2,2089 & 2,136 & 2,087 & 2,125 & 2,034 & 2,094 & \multirow[t]{2}{*}{ Min 2,270 } \\
\hline & \multicolumn{7}{|c|}{ Rata-rata 2,098} & \\
\hline \multirow[t]{2}{*}{ Stabilitas (kg) } & 2791,8 & 2895,2 & 2998,6 & 2998,6 & 2998,6 & 2895,2 & 2326,5 & \multirow[t]{2}{*}{ Min 800} \\
\hline & \multicolumn{7}{|c|}{ Rata-rata 2843,5} & \\
\hline \multirow{2}{*}{$\begin{array}{l}\text { Flow/kelelehan } \\
\text { (mm) }\end{array}$} & 7,2 & 3,2 & 4,8 & 6,5 & 2,7 & 6,4 & 3,6 & \multirow[t]{2}{*}{$2,0-4,0$} \\
\hline & \multicolumn{7}{|c|}{ Rata-rata 4,91} & \\
\hline \multirow[t]{2}{*}{ VIM (\%) } & 11,366 & 12,704 & 10,740 & 12,787 & 11,199 & 15,002 & 12,495 & \multirow[t]{2}{*}{$3,0-5,0$} \\
\hline & & & & -rata 1 & & & & \\
\hline \multirow[t]{2}{*}{ VFB (\%) } & 49,549 & 46,392 & 51,140 & 46,208 & 49,966 & 41,642 & 46,864 & \multirow[t]{2}{*}{ Min 65} \\
\hline & & & & -rata 4 & & & & \\
\hline \multirow[t]{2}{*}{ VMA (\%) } & 22,529 & 23,698 & 21,981 & 23,771 & 22,383 & 25,707 & 23,515 & \multirow[t]{2}{*}{ Min 15} \\
\hline & & & & -rata 2 & & & & \\
\hline \multirow[t]{2}{*}{ MQ (kg/mm) } & 387,75 & 904,75 & 624,71 & 461,32 & $\begin{array}{c}1110,5 \\
9\end{array}$ & 452,37 & 646,25 & \multirow[t]{2}{*}{ Min 250} \\
\hline & \multicolumn{7}{|c|}{ Rata-rata 655,39} & \\
\hline
\end{tabular}

Table 2. Hasil pengujian Marshall Test dengan penambahan Plastik HDPE dengan Variasi 7,5\%.

\begin{tabular}{|c|c|c|c|c|c|c|c|c|}
\hline \multirow{2}{*}{$\begin{array}{c}\text { Hasil } \\
\text { Pemeriksaan }\end{array}$} & \multicolumn{7}{|c|}{ Penambahan Plastik 7,5\% } & \multirow[t]{2}{*}{ Spesifikasi } \\
\hline & 1 & 2 & 3 & 4 & 5 & 6 & 7 & \\
\hline \multirow{2}{*}{$\begin{array}{l}\text { Kepadatan } \\
(\mathrm{gr} / \mathrm{ml})\end{array}$} & 1,989 & 2,029 & 2,028 & 2,014 & 1,961 & 2,087 & 2,017 & \multirow[t]{2}{*}{ Min 2,270 } \\
\hline & \multicolumn{7}{|c|}{ Rata-rata 2,018} & \\
\hline \multirow[t]{2}{*}{ Stabilitas (kg) } & 2843,5 & 3360,5 & 2998,6 & 2843,5 & 2688,4 & 1447,6 & 2688,4 & \multirow[t]{2}{*}{ Min 800} \\
\hline & & & & a-rata & 95,8 & & & \\
\hline \multirow{2}{*}{$\begin{array}{l}\text { Flow/kelelehan } \\
(\mathrm{mm})\end{array}$} & 7,1 & 6,1 & 4,6 & 3,7 & 3,1 & 2,5 & 3,7 & \multirow[t]{2}{*}{$2,0-4,0$} \\
\hline & \multicolumn{7}{|c|}{ Rata-rata 4,4} & \\
\hline
\end{tabular}




\begin{tabular}{|c|c|c|c|c|c|c|c|c|}
\hline \multicolumn{9}{|c|}{ Lanjutan Tabel 2} \\
\hline \multirow[t]{2}{*}{ VIM (\%) } & 16,883 & 15,211 & 15,253 & 15,838 & 18,053 & 12,787 & 15,712 & \multirow[t]{2}{*}{$3,0-5,0$} \\
\hline & \multicolumn{7}{|c|}{ Rata-rata 16,677 } & \\
\hline \multirow{2}{*}{ VFB (\%) } & 47,389 & 50,491 & 50,410 & 49,296 & 45,370 & 55,513 & 49,534 & \multirow[t]{2}{*}{ Min 65} \\
\hline & \multicolumn{7}{|c|}{ Rata-rata 49,715} & \\
\hline \multirow[t]{2}{*}{ VMA (\%) } & 32,090 & 30,724 & 30,758 & 31,236 & 33,046 & 28,743 & 31,134 & \multirow[t]{2}{*}{ Min 15} \\
\hline & \multicolumn{7}{|c|}{ Rata-rata 31,104 } & \\
\hline \multirow[t]{2}{*}{ MQ (kg/mm) } & 400,5 & 550,9 & 651,87 & 768,51 & 867,51 & 965,06 & 726,6 & \multirow[t]{2}{*}{ Min 250} \\
\hline & \multicolumn{7}{|c|}{ Rata-rata 704,38} & \\
\hline
\end{tabular}

Table 3. Hasil pengujian Marshall Test dengan penambahan Plastik HDPE dengan Variasi $10 \%$.

\begin{tabular}{|c|c|c|c|c|c|c|c|c|}
\hline \multirow{2}{*}{$\begin{array}{c}\text { Hasil } \\
\text { Pemeriksaan }\end{array}$} & \multicolumn{7}{|c|}{ Penambahan Plastik 10\% } & \multirow{2}{*}{ Spesifikasi } \\
\hline & 1 & 2 & 3 & 4 & 5 & 6 & 7 & \\
\hline \multirow{2}{*}{$\begin{array}{l}\text { Kepadatan } \\
\text { (gr/ml) }\end{array}$} & 2,048 & 2,051 & 2,016 & 1,986 & 1,958 & 2,005 & 1,980 & $\operatorname{Min} 2,270$ \\
\hline & \multicolumn{7}{|c|}{ Rata-rata 2,006} & \\
\hline \multirow[t]{2}{*}{ Stabilitas (kg) } & 2791,8 & 2429,9 & 2347,2 & 2171,4 & 2357,5 & 2347,2 & 2740,1 & Min 800 \\
\hline & \multicolumn{7}{|c|}{ Rata-rata 2455,0} & \\
\hline \multirow{2}{*}{$\begin{array}{l}\text { Flow/kelelehan } \\
\text { (mm) }\end{array}$} & 1 & 1,1 & 1,4 & 1,7 & 2,8 & 1,2 & 2,2 & $2,0-4,0$ \\
\hline & \multicolumn{7}{|c|}{ Rata-rata 1,63} & \\
\hline \multirow[t]{2}{*}{ VIM (\%) } & 14,417 & 14,292 & 15,754 & 17,008 & 18,178 & 16,214 & 17,259 & $3,0-5,0$ \\
\hline & \multicolumn{7}{|c|}{ Rata-rata 16,160} & \\
\hline \multirow[t]{2}{*}{ VFB (\%) } & 42,778 & 43,028 & 40,244 & 38,063 & 36,179 & 39,423 & 37,646 & Min 65 \\
\hline & \multicolumn{7}{|c|}{ Rata-rata 39,623} & \\
\hline \multirow[t]{2}{*}{ VMA (\%) } & 25,195 & 25,086 & 26,364 & 27,460 & 28,483 & 26,766 & 27,679 & Min 15 \\
\hline & \multicolumn{7}{|c|}{ Rata-rata 26,719 } & \\
\hline \multirow[t]{2}{*}{ MQ (kg/mm) } & 2791,8 & 2209 & 16766,56 & 1277,30 & 841,97 & 1955,99 & 1245,5 & \multirow[t]{2}{*}{ Min 250} \\
\hline & & & & -rata 17 & ,02 & & & \\
\hline
\end{tabular}

\section{a. Kepadatan (Density)}

Berdasarkan Tabel 1. diatas menunjukan bahwa penambahan plastik $5 \%$ menghasilkan nilai rata-rata kepadatan 2,098 $(\mathrm{g} / \mathrm{cc})$, pada penambahan plastik 7,5\% dengan nilai rata-rata $2,018(\mathrm{~g} / \mathrm{cc})$, dan pada penambahan plastik $10 \%$ dengan nilai rata-rata 2,006 $(\mathrm{gr} / \mathrm{cc})$.

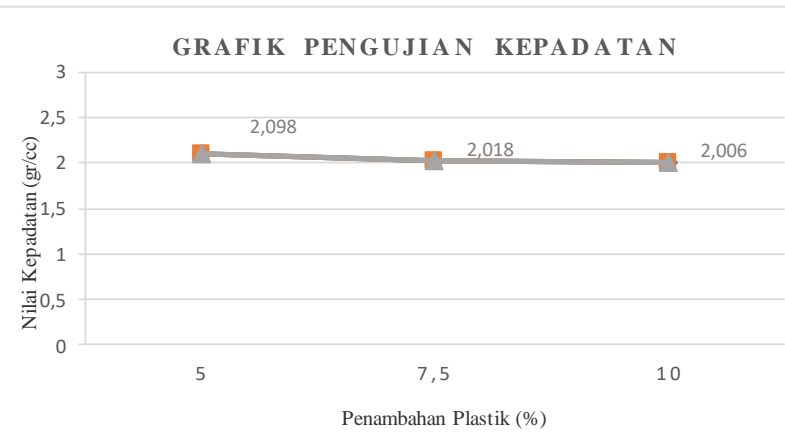

Gambar 2. Grafik hubungan kepadatan (Density) dan campuran plastic

Dari Gambar 2 diatas terlihat bahwa nilai kepadatan maksimum dapat diperoleh dengan pencampuran $5 \%$ plastic dan terendah diperoleh oleh pencampuran $10 \%$ plastic. Dengan demikian semakin banyak peresentasi plastic yang ditambahkan akan mengurangi kepadatan dari campuran aspal yang dihasilkan.

\section{b. Stabilitas}

Dari Gambar 2. diatas menunjukan bahwa hubungan stabilitas dengan penambahan plastik di atas, pada penambahan plastik $5 \%, 7,5 \%$, dan $10 \%$, Nilai stabilitas berturut- turut mengalami penurunan sebesar $146,71 \%$, dan 240,8 \% terhadap nilai stabilitas 5\% .Nilai stabilitas Marshall Optimum tercapai pada campuran beton aspal dengan penambahan plastik 5\% dengan hasil rata-rata nilai stabilitas sebesar $2843,5 \mathrm{~kg}$.

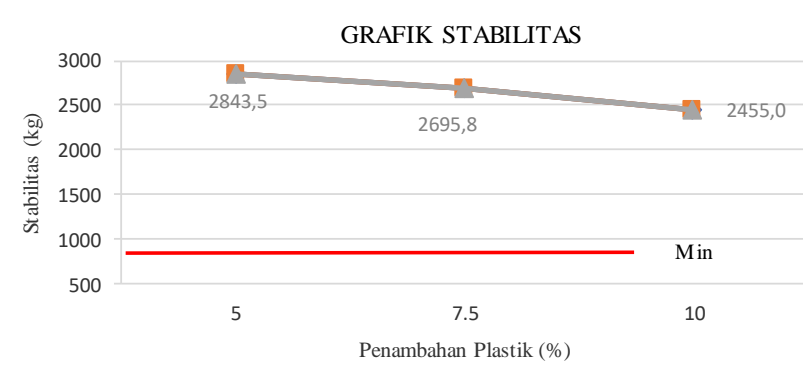

Gambar 3. Grafik hubungan Stabilitas dan campuran plastic

Dari Gambar 3 terlihat bahwa nilai stabilitas Marshall Optimum tercapai pada campuran beton aspal dengan penambahan plastik 5\% dengan hasil rata-rata nilai stabilitas sebesar 2843,5 kg.

Berdasarkan Spesifikasi Umum Bina Marga Revisi 2010 tentang ketentuan sifat-sifat campuran laston nilai stabilitas minimum untuk lalu lintas berat yaitu 800 $\mathrm{kg}$, sehingga semua kadar aspal yang digunakan dalam penelitian ini memenuhi persyaratan yang ada.

c. Flow

Pengaruh penambahan plastik terhadap flow/ kelelehan campuran AC-WC dapat kita lihat pada Tabel 1,Tabel 2 dan Table 3. yaitu pengaruh penambahan 
plastik sebanyak $5 \%$, ke 7,5\% mengalami penurunan sebanyak $0,65 \mathrm{~mm}$ lalu pada penambahan plastik dari $7,5 \%$ ke $10 \%$ mengalami penurunan sebanyak $2,63 \mathrm{~mm}$

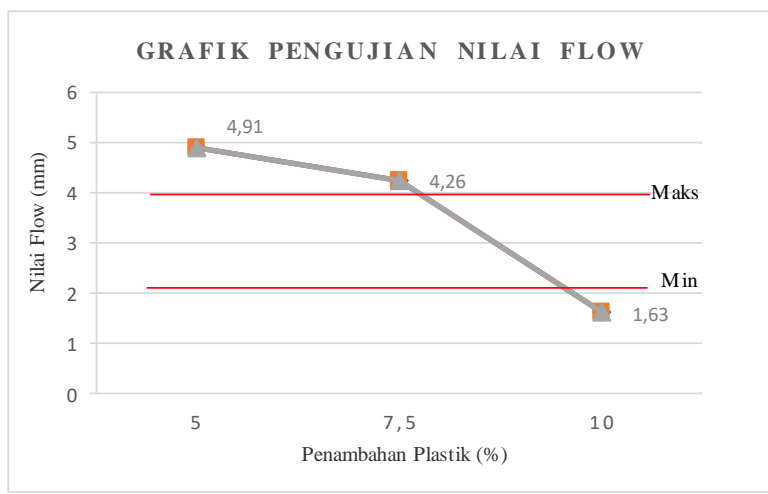

Gambar 4. Grafik hubungan flow dan campuran plastic

Sehingga Gambar 4. dapat disimpulkan semakin banyak campuran plastik yang digunakan maka nilai flow juga semakin menurun. Dari besarnya nilai flow tertinggi terdapat pada campuran plastik sebanyak 5\% dengan ratarata sebesar 4,91 mm. Sedangkan jika ditinjau dari Spesifikasi Umum Bina Marga Revisi 2010 tentang ketentuan sifat-sifat campuran Laston limbah plastik nilai flow Minimal $2 \mathrm{~mm}$ dan Maksimal $4 \mathrm{~mm}$. Sehingga dari penelitian yang dilakukan terhadap penambahan plastik $5 \%, 7,5 \%$ dan $10 \%$ tidak ada yang memenuhi persyaratan SNI Bina Marga 2010 yang ada

\section{d. Void Filled Bitumen}

Pengaruh penambahan plastik terhadap VFB campuran AC-WC dapat dilihat pada Tabel 1,Tabel 2 dan Table 3 yaitu Nilai VFB (Void Filled Bitumen) pada penambahan plastik sebanyak 5\% dengan rata-rata 47,394 $\%$, penambahan plastik $7,5 \%$ dengan rata-rata $49,715 \%$ dan penambahan plastik yang $10 \%$ dengan rata-rata $39,623 \%$.

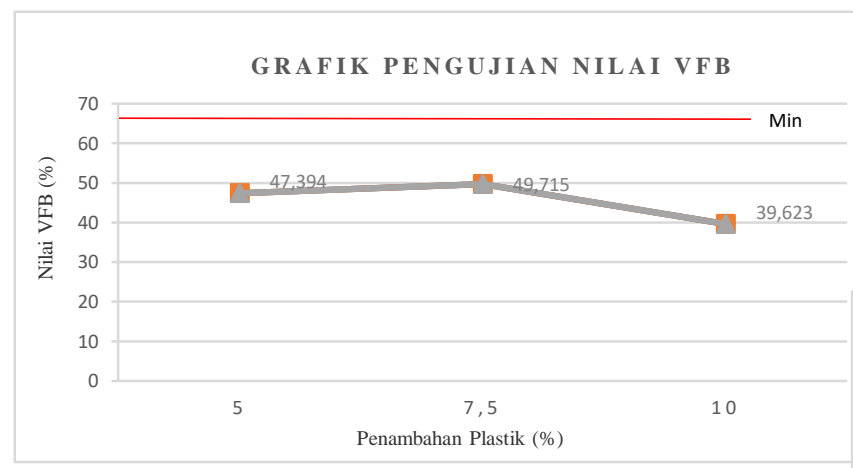

Gambar 5. Grafik hubungan VIB dan campuran plastic

Nilai VFB (Void Filled Bitumen) pada Gambar 5 dari campuran $5 \%$ ke 7,5\% mengalami kenaikan sebesar 2,321\%, sedangkan dari penambahan plastik 7,5\% ke penambahan plastik $10 \%$ mengalami penurunan sebesar 10,092 \%. Dari Gambar 5. nilai VFB (Void Filled Bitumen) tertinggi didapat pada grafik plastik yang $7,5 \%$ dengan nilai rata-rata yaitu $47,715 \%$.
Dari persyaratan Spesifikasi Umum Bina Marga Revisi 2018 tentang ketentuan sifat-sifat campuran laston nilai VFB (Void Filled Bitumen) harus $>68 \%$. Nilai VFB (Void Filled Bitumen) sehingga dapat disimpulkan yang tidak memenuhi persyaratan yaitu pada campuran plastik $5 \%, 7,5 \%$ maupun campuran plastik yang $10 \%$.

\section{e. Voids In Mix (VIM)}

Pengaruh penambahan plastik terhadap VIM campuran AC-WC pada Tabel 1,Tabel 2 dan Table 3 Memperlihatkan nilai VIM (Void In Mix) pada penambahan plastik $5 \%$ dengan rata-rata $12,328 \%$, pada penambahan plastik 7,5\% dengan rata-rata $15,677 \%$, dan penambahan plastik yang $10 \%$ dengan rata-rata $16,160 \%$.

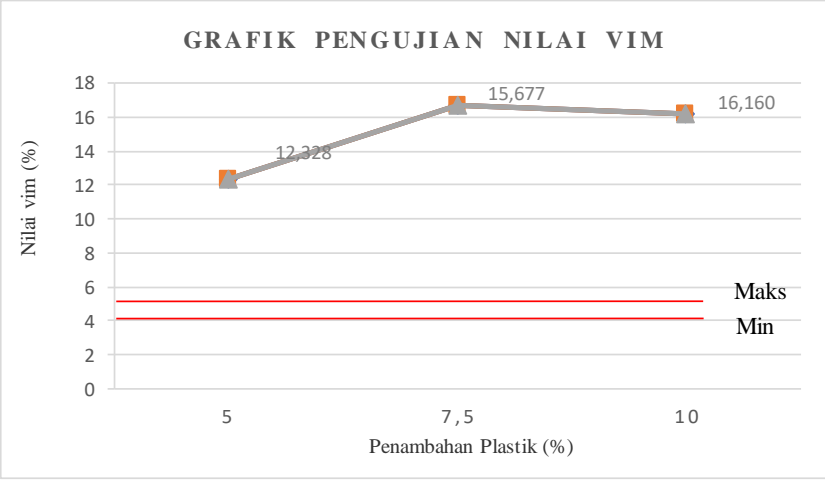

Gambar 6. Grafik hubungan VIM dan campuran plastic

Dari Gambar 6 didapat nilai VIM (Void In Mix) yang tertinggi yaitu pada penambahan plastik $10 \%$ dengan ratarata $16,160 \%$. Berdasarkan persyaratan Spesifikasi Umum Bina Marga Revisi 2018 tentang ketentuan sifat-sifat campuran Laston nilai VIM (Void In Mix) dari ketiga nya tidak ada yang sesuai dengan persyaratan yang ada.

\section{f. VMA (Void In Mineral Aggregat)}

Pada Tabel 1,Tabel 2 dan Table 3 Pengaruh penambahan plastik terhadap VMA campuran AC-WC yaitu Nilai VMA (Void In Mineral Aggregate) pada Penambahan Plastik sebanyak 5\% dengan rata-rata sebesar 23,369 \%, pada penambahan plastik 7,5\% dan $10 \%$ mengalami peningkatan sebesar 31,104\%, sedangkan pada penambahan plastik yang $10 \%$ mengalami penurunan sebesar 26,719\%.

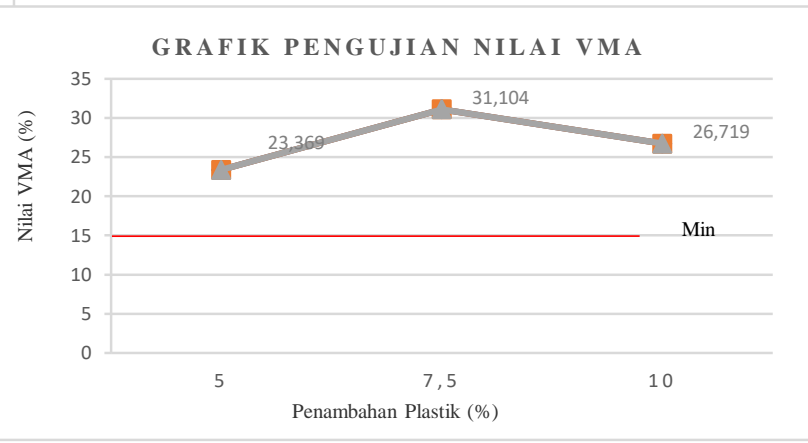

Gambar 7. Grafik hubungan VMA dan campuran plastic 
Ditinjau dari Spesifikasi Umum Bina Marga Revisi 2018 tentang ketentuan sifat-sifat campuran Laston nilai VMA (Void In Mineral Aggregate) minimal sebesar 15\%, $>13 \%$, jadi dari penambahan plastik $5 \%, 7,5 \%$ dan $10 \%$ semuanya memenuhi persyaratan nilai VMA (Void In Mineral Aggregate) yang sesuai dengan SNI Bina Marga 2010 seperti pada Gambar 7.

\section{g. MQ (Marshall Quotient)}

Pengaruh penambahan plastik terhadap Marshall Quotient campuran AC-WC yaitu hubungan MQ (Marshall Quotient) dan penambahan plastik, pada Tabel 1,Tabel 2 dan Tabel 3 terlihat penambahan plastik 5\%, $7,5 \%$ dan $10 \%$ berturut-turut mengalami kenaikan sebesar 655,39 (kg/mm), 704,38 (kg/mm), dan 1714,02 $(\mathrm{kg} / \mathrm{mm})$.

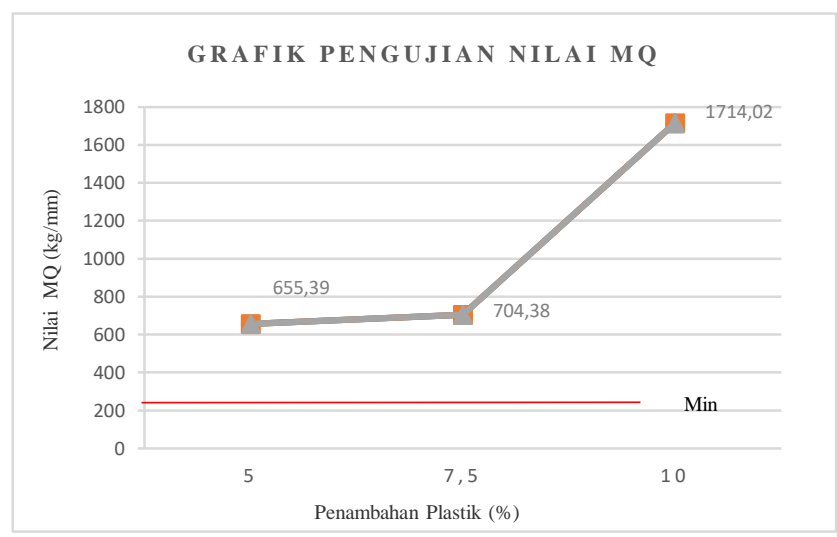

Gambar 8. Nilai Marshall Quotient

Dari Gambar 8 menunjukan bahwa campuran beton aspal dengan penambahan plastik $10 \%$ memiliki nilai MQ (Marshall Quotient) tertinggi yaitu 1714,02 kg/mm. Secara keseluruhan campuran beton aspal menggunakan agregat bantak memenuhi syarat MQ berdasarkan Spesifikasi Umum Bina Marga Revisi 2018 yaitu > 250 $\mathrm{kg} / \mathrm{mm}$.

\section{KESIMPULAN}

Berdasarkan hasil penelitian ini, dapat disimpulkan beberapa hal mengenai pengaruh penambahan limbah plastik jenis HDPE ( High Density Polyethylene) terhadap lapis aspal AC-WC adalah :

1) Penambahan limbah plastik type HDPE ( High Density Polyethylene ) berpengaruh terhadap laspisan aspal AC-WC. Aspal beton pada penambahan plastik HDPE dapat meningkatkan mutu campuran. Penambahan plastik ke agregat bisa meningkatkan kekuatan agregat terhadap abrasi dan mengurasi pengerapan.

2) Nilai kuat tekan aspal AC-WC dengan menggunakan metode pengujian Stabilitas sampai pengujian Marshall Quotient dengan menggunakan Masrhall Test antara lain :

- Nilai stabilitas terbaik adalah ada pada penambahan plastik $5 \%$ dengan nilai $2843,5 \mathrm{~kg}$.

- Nilai density campuran aspal dengan penambahan plastik $5 \%$ dengan nilai 2,098gr/ml, menurun sebanyak 0,08 pada penambahan plastik $7,5 \%$, dan terus menurun sebesar $0,012 \mathrm{gr} / \mathrm{ml}$ pada penambahan plastik $10 \%$.

- Nilai VIM pada campuran aspal dengan penambahan plastik 5\% dengan nilai $12,328 \%$, dan meningkat pada penambahan plastik $7,5 \%$ dengan nilai $15,677 \%$, dan terus meningkat pada penambahan plastik $10 \%$ dengan nilai $16,160 \%$.

- Nilai VMA pada campuran aspal dengan penambahan plastik 5\% dengan nilai $23,369 \%$, dan meningkat pada penambahan plastik 7,5\% dengan nilai $31,104 \%$ dan pada penambahan plastik $10 \%$ kembali menurun dengan nilai $26,719 \%$.

- Nilai VFB pada campuran aspal dengan penambahan plastik 5\% dengan nilai $47,394 \%$, dan meningkat pada penambahan plastik $7,5 \%$ dengan nilai 49,715\%, kemudian kembali menurun dengan nilai $39,623 \%$.

- Nilai flow (kelelehan) pada campuran aspal dengan penambahan plastik $5 \%$ dengan nilai $4,91 \mathrm{~mm}$ dan menurun pada penambahan plastik $7,5 \%$ dengan nilai $4,26 \mathrm{~mm}$ dan terus menurun pada penambahan plastik $10 \%$ dengan nilai 1,63 $\mathrm{mm}$.

- Nilai Marshall Quotien pada campuran aspal dengan penambahan plastik 5\% dengan nilai $655,39 \mathrm{~kg} / \mathrm{mm}$, dan meningkat pada penambahan plastik 7,5\% dengan nilai 704,38 kg/mm, dan terus meningkat pada penambahan plastik $10 \%$ dengan nilai $1714,02 \mathrm{~kg} / \mathrm{mm}$.

\section{DAFTAR PUSTAKA}

A Technique to Dispose Waste Plastics in an Ecofriendly Way - Application in Construction of Flexible Pavements. Tamil Nadu: Elsevier Ltd.

Construction of Flexible Pavements. Tamil Nadu: Elsevier Ltd. Departemen Permukiman dan Pengembangan Wilayah, ( 2004 )

Direktorat Jendral Bina Marga. 2010. Departemen Pekerjaan Umum, Pekerjaan

Lapis Pondasi Jalan, Buku 1 Umum, Manual Konstruksi dan Bangunan. Jakarta: Departemen Pekerjaan Umum.

Hermawan, Okky Hendra.2018. Pengaruh Perawatan Terhadap Kuat Tekan Beton.Volume no 16. Dosen Teknik Sipil Universitas Pancasakti Tegal.

Hirst, E., \& Brown, M. (1990). Closing the efficiency gap: barriers to the efficient use of energy. Resources, Conservation and Recycling.

Lapian, F. E. P., Ramli, M. I., Pasra, M., \& Arsyad, D. A. (2019). Pengaruh Limbah Plastik PET (Polyethylene Teterphthalate) terhadap Nilai Kadar Aspal Optimum Campuran AC-WC. Adaptasi Dan Mitigasi Bencana Dalam Mewujudkan Infrastruktur Yang Berkelanjutan, November, 139-149.

Mirajhusnita, I., Santosa, T. H., \& Hidayat, R. (2020). Pemanfaatan Limbah B3Sebagai Bahan Pengganti Sebagian Agregat Halus Dalam Pembuatan Beton. 1(1), 24-33. 
Peacock, A. J. 2000. Handbook of Polyethylene ( Structures, Properties, and Applications ). New York, USA : Marcel Dekker, Inc.

P, P., Diansyah., Surabaya, U. N., Mahardi, P., Sc, M., \& Risdianto, Y. (n.d.). .

Simanjuntak, S., Saragi, Y. 2012. Analisa Perbandingan Kualitas Aspal Beton Dengan Filler Bentonite. Medan: Lembaga Penelitian Universitas HKBP Nommensen.

Sukirman, S, ( 2003 ) Beton Aspal Campuran Panas, Nova, Bandung.

Supriyanto, Mudjanarko, S. W., Koespiadi, \& Limantara, A. D. (2019). Studi Penggunaan Variasi Campuran Material Plastik Jenis High Density Polyethylene ( Hdpe ) Pada Campuran Beraspal Untuk Lapis Aus Ac- Wc ( Asphalt Concrete Wearing Course ). Paduraksa, 8(2), 222-233.

Sri, :, \& Purwonugroho, W. (2018). Pengolahan Limbah Plastik High Density Polyethylene (Hdpe) dan Polyprophylene $(\mathrm{Pp})$ dengan metode Mix Plastic Coated Aggregate untuk meningkatkan kualitas aspal beton. Skripsi.

Susanto, I., \& Suaryana, N. (2019). Evaluasi Kinerja Campuran Beraspal Lapis Aus (AC-WC) dengan Bahan Tambah Limbah Plastik Kresek. Jurnal Aplikasi Teknik Sipil, 17(2), 27.

Tripoli, B., Teknik, D., Fakultas, S., Universitas, T., Umar, T., Sipil, J. T., Teknik, F., \& Teuku, U. (2020). Studi Karakteristik Marshall pada Campuran Aspal dengan Penambahan Kresek. 6(2), 30-40.

Utomo, T. ., Hasanudin, U., \& Suroso, E. (2010). World Congress on Engineering: WCE 2010:30 June - 2 July, 2010, Imperial College London, London, U.K. Proceedings of the World Congress on Engineering 2010.

Yolly, Detra., Asrar, 2007. Karakteristik Aspal Dengan Bahan Tambah Plastik dan Kinerjanya dalam Campuran HRA. Departemen Civil and Engineering, Medan. 